San Jose State University

SJSU ScholarWorks

Master's Theses

Master's Theses and Graduate Research

1989

\title{
Effects of the words, "acquired, immune, AIDS and deficiency," on students' perceived anxiety
}

John C. Woody

San Jose State University

Follow this and additional works at: https://scholarworks.sjsu.edu/etd_theses

\section{Recommended Citation}

Woody, John C., "Effects of the words, "acquired, immune, AIDS and deficiency," on students' perceived anxiety" (1989). Master's Theses. 3121.

DOI: https://doi.org/10.31979/etd.yrwg-pub7

https://scholarworks.sjsu.edu/etd_theses/3121

This Thesis is brought to you for free and open access by the Master's Theses and Graduate Research at SJSU ScholarWorks. It has been accepted for inclusion in Master's Theses by an authorized administrator of SJSU ScholarWorks. For more information, please contact scholarworks@sjsu.edu. 


\section{INFORMATION TO USERS}

The most advanced technology has been used to photograph and reproduce this manuscript from the microfilm master. UMI films the text directly from the original or copy submitted. Thus, some thesis and dissertation copies are in typewriter face, while others may be from any type of computer printer.

The quality of this reproduction is dependent upon the quality of the copy submitted. Broken or indistinct print, colored or poor quality illustrations and photographs, print bleedthrough, substandard margins, and improper alignment can adversely affect reproduction.

In the unlikely event that the author did not send UMI a complete manuscript and there are missing pages, these will be noted. Also, if unauthorized copyright material had to be removed, a note will indicate the deletion.

Oversize materials (e.g., maps, drawings, charts) are reproduced by sectioning the original, beginning at the upper left-hand corner and continuing from left to right in equal sections with small overlaps. Each original is also photographed in one exposure and is included in reduced form at the back of the book. These are also available as one exposure on a standard $35 \mathrm{~mm}$ slide or as a $17^{\prime \prime} \times 23^{\prime \prime}$ black and white photographic print for an additional charge.

Photographs included in the original manuscript have been reproduced xerographically in this copy. Higher quality $6^{\prime \prime} \times 9^{\prime \prime}$ black and white photographic prints are available for any photographs or illustrations appearing in this copy for an additional charge. Contact UMI directly to order.

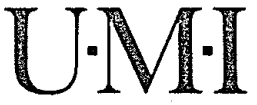


Order Number 1337855

Effects of the words, "acquired, immune, AIDS and deficiency," on students' perceived anxiety

Woody, John Carmen, M.S.

San Jose State University, 1989

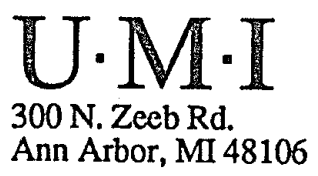


, 


\title{
EFFECTS OF THE WORDS, \\ "ACQUIRED, IMMUNE, AIDS AND DEFICIENCY," \\ ON STUDENTS' PERCEIVED ANXIETY
}

\author{
A Thesis \\ Presented to \\ The Faculty of the Department of Nursing \\ San Jose State University
}

In Partial Fulfillment

of the Requirements for the Degree

Master of science

By
John C. Woody
August, 1989 
APPROVED FOR THE DEPARTMENT OF NURSING

Virgie Parsons

Virgil Parsons, DNSC, RN

Babluje Eosenber

Bobby Gutenberg, NSc, RU, C

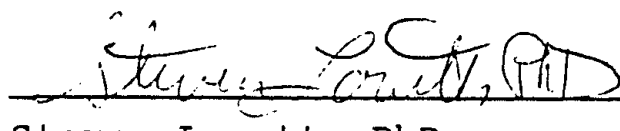

Steven Lovett, PhD

APPROVED FOR THE UNIVERSITY

Serena At. Stanguere 


$$
\begin{gathered}
\text { ABSTRACT } \\
\text { EFFECTS OF THE WORDS, } \\
\text { "ACQUIRED, IMMUNE, AIDS AND DEFICIENCY," } \\
\text { ON STUDENTS' PERCEIVED ANXIETY } \\
\text { by John C. WOOdY }
\end{gathered}
$$

This research used a multiple group, experimental, masked study design to determine if an undercurrent of anxiety in response to the subject of AIDS was evident, and whether this level of anxiety had any relationship to knowledge about AIDS. The setting was a state university in northern California. Using the Stait-Trait Anxiety Inventory, no undercurrent of anxiety in response to the subject of AIDS was demonstrated. A significant negative correlation was demonstrated for perceived anxiety and knowledge about AIDS; subjects scoring high on AIDS knowledge scored low on perceived anxiety, $\underline{r}=-.299$, $p<.05$. Based on the findings, recommendations are made for further studies that would differentiate between positive and negative forms of information about AIDS which woild serve to decrease anxiety in response to the subject of AIDS. 


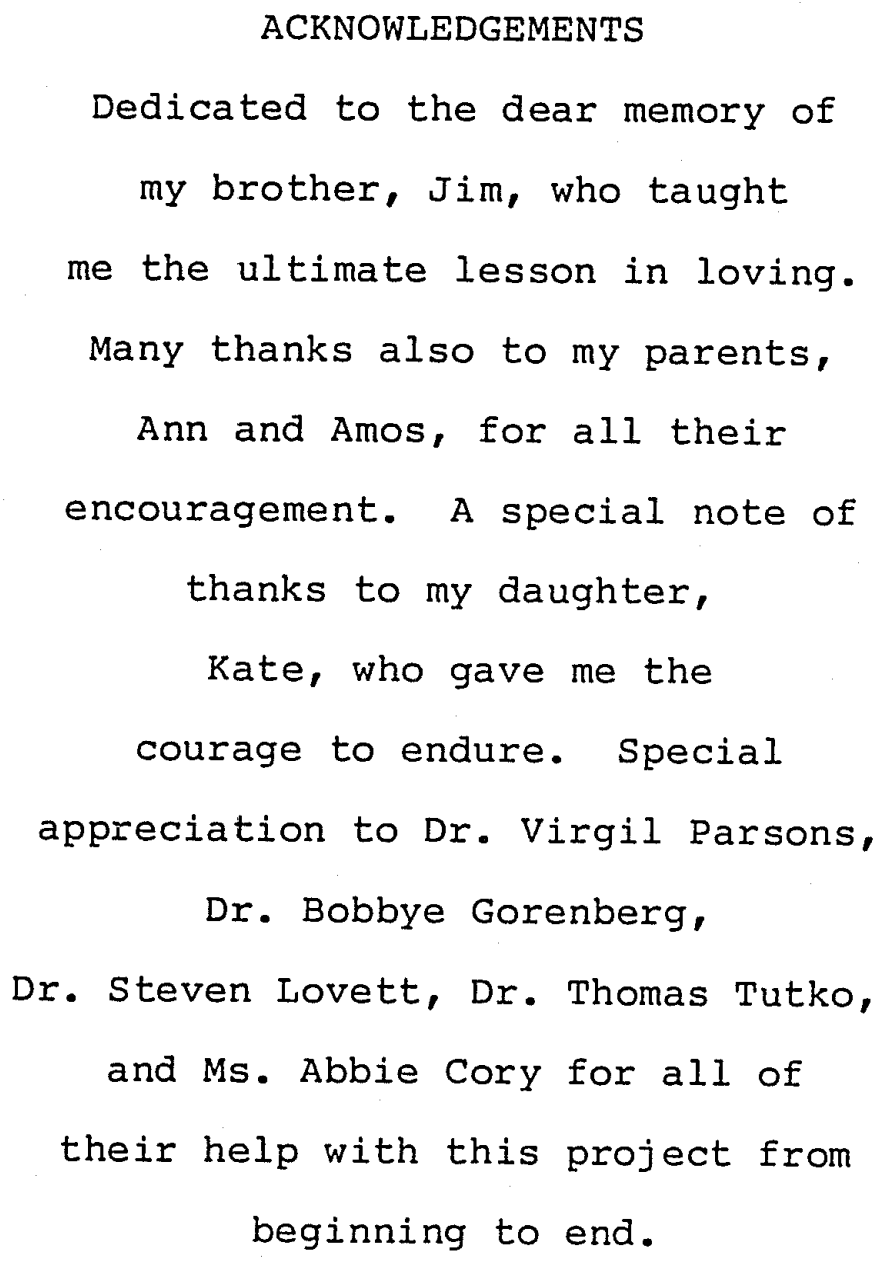


TABLE OF CONTENTS

Page

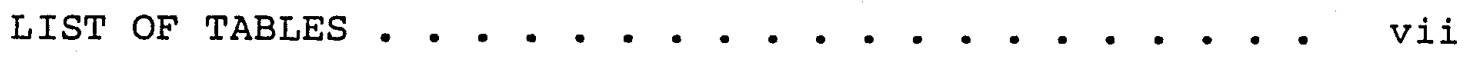

LIST OF FIGURES • . . . . . . . . . . . . . . . . viii Chapter

1. INTRODUCTION $. . . \cdot . \cdot . \cdot . \cdot . \cdot . \cdot . \cdot 1$

Statement of the Problem . . . . . . . 2

Research Questions . . . . . . . . 4

Purpose and Need ............ . 4

Definition of Terms . . . . . . . . . 5

Research Design . . . . . . . . . 7

Scope and Limitations . . . . . . . . 7

2. CONCEPTUAL FRAMEWORK AND REVIEW

OF LITERATURE • • • • • • • • • • • • • • 9

Conceptual Framework . . . . . . . . . 9

Review of the Literature . . . . . . . 13

3. METHODOLOGY . . . . • . . . • . . 17

Research Design . . . . . . . . . 17

Sample and setting . . . . . . . . 18

Instrument . . . . . . . . . • . 18

Data Collection Method . . . . . . . 20

4. ANALYSIS AND INTERPRETATION OF DATA - • • • • 23

Data Collection and Analysis . . . . . . 23 
5. CONCLUSIONS AND RECOMMENDATIONS ...... . 27

Conclusions . . . . . . . . . 27

Recommendations .......... . 29

REFERENCES .................. . 31

APPENDIXES

A. Newspaper Clipping . . . . . . 35

B. Survey Packet on Classroom Lighting . . 37

C. Permission to Conduct Study ...... 50 


\section{LIST OF TABLES}

Table

Page

1. ANOVA Summary Table Comparing Differences

for STAI, Attentiveness, and AIDS

Knowledge Scores . . . . . . . . 25

2. Intercorrelation Among STAI Scores, AIDS

Knowledge, and Attentiveness . . . . . 25 


\section{LIST OF FIGURES}

Figure Page

1. The Betty Neuman Model: A Total Person

Approach to Patient Problems . . . . . 11

viii 


\section{Chapter 1}

\section{INTRODUCTION}

The epidemic of Acquired Immune Deficiency Syndrome (AIDS) has to date claimed the lives of over 42,000 Americans and has evoked much fear and controversy since it first appeared in 1981. Since that year, over 74,000 Americans have been infected with the deadly virus, and over half of those individuals have died (Certers for Disease Control, 1988). The disease has become pandemic, with over 250,000 cases estimated to have already occurred, and as many as 10 million people are believed to be infected worldwide (Mann, Chin, Piot, \& Quinn, 1988).

This study was designed to determine if an undercurrent of anxiety exists in response to the subject of AIDS and whether knowledge about AIDS has any impact on perceived anxiety. This determination may prove important, because unreasonable fears and anxieties can be as crippling as the disease itself (Koop, 1986). While some measure of stress can be essential to survival, too much stress and anxiety can be detrimental to health and proper functioning (stuart \& Sundeen, 1983, p. 120). As the epidemic expands, irrational fears and negative biases towards select groups of people will need to be addressed through enhanced educational campaigns as well as other services.

Feelings of anxiety produced in response to the subject 
of AIDS are predictable, because, as stuart and Sundeen (1983) state, anxiety is a product of a perceived threat to one's well-being, self-esteem, or integrity (p. 972). Studies that serve to demonstrate a link between feelings of anxiety to a stressor and the effect that education may have on this state of anxiety may prove valuable in the defense of future educational efforts.

statement of the Problem

While the general concern over the disease of AIDS may vary from person to person, it is possible that a common denominator linking every individual to the epidemic might be found in the amount of anxiety a person encounters unknowingly in response to the subject of AIDS. A study designed to determine if increased anxiety is an unavoidable consequence of living in a society immersed in this deadly disease would help in encouraging members of that society to rationally address the problem through preventive education.

Such a study might take advantage of the psycholinguistic effect known as semantic conditioning (Navarick, 1979, p. 404). Semantic conditioning is a form of classical conditioning in which the conditioned and/or unconditioned stimulus is a word, phrase, or sentence. Both in theory and in research, studies have demonstrated that the meaning one ascribes to certain words often reflects one's attitudes towards certain concepts (Osgood, 1965, p. 286). As concepts are created or changed, the meaning of 
once neutral words are also changed where such words comprise associations to the new concepts. The effects of semantic conditioning might help explain the recent lag in sales for the diet suppressant, AYDS (Appendix A). Consumers appear to be associating that product name with the disease (Horovitz, 1988). Apparently, the concern about AIDS does indeed affect people's behavior, often in unlikely ways.

The effects of semantic conditioning may be responsible for a heightened sense of anxiety relative to the subject of AIDS. The basic assumption underlying this notion is that classical conditioning factors are at work in the environment and can often explain complex behaviors such as phobias and fetishes (Baron \& Byrne, 1977, pp. 460-461). The existing body of research on stress related to the topic of AIDS appears to be confined primarily to those with AIDS or those caring for people with AIDS. There seems to be a lack of data on how stress and anxiety affect people in general and how education and knowledge about AIDS impacts on this level of anxiety. However, O'Donnell and O'Donnell (1987) demonstrated that education on the transmission of AIDS reduced caregivers' perceived stress. Whereas the O'Donnells' study examined the conscious aspects of stress, this study focused on the unconscious origins of anxiety in response to the subject of AIDS. 
Research Questions

This study sought to determine if the words, Acquired, Immune, Aids, and Deficiency, would elicit an anxiety response, presumably acquired through the process of semantj.c conditioning, and if knowledge about AIDS had any relationship to this anxiety. The following research questions were asked:

1. Have the words, Acquired, Immune, Aids, and Deficiency, become conditioned stimuli that elicit an anxiety response in individuals?

2. Is there a relationship between perceived anxiety and knowledge about AIDS?

3. Does the process of semantic conditioning operate at a point below one's level of awareness? It was inferred in this study that these three possibilities might exist given the past research on the effects of semantic conditioning.

\section{Purpose and Need}

The purpose of this study was to determine if individuals experienced anxiety when exposed to the subject of AIDS as manifested in the words, Acquired, Immune, Aids, and Deficiency. Explication of this anxiety would provide evidence that the disease to some measure involves everyone; therefore, it is a responsibility of each member in society to address the issue by obtaining factual information.

The subject of education was examined, because the 
key to changing attitudes and behaviors is to provide consistent, factual, and unbiased information on how AIDS is transmitted (Koop, 1986). Due to discrimination against persons with AIDS and those believed to be infected with the virus, the Surgeon General, the American Medical Association (AMA), and the American Nurses' Association (ANA) propose that education is the only practical means presently available to fight the epidemic.

Discrimination continues, because fear of a perceived threat often results in anger, tension, and resentment (Stearns, 1972, p. 6). Anger is a feeling of resentment. that occurs in response to heightened anxiety when the person perceives a threat (Stuart \& Sundeen, 1983, p. 119). As more controversial measures arise proposing mandatory testing, tracking, and possible internment of persons suspected of being infected with AIDS, arguments for sound educational approaches will become imperative. Studies showing that AIDS education decreases anxiety about the disease will lend weight to these arguments.

\section{Definition of Terms}

For this study, the following definitions were used:

1. Stress is a subjective state of tension within the individual and can be caused by physical or psychological stimuli which the individual perceives as challenging or threatening (Stuart \& Sundeen, 1983, p. 119).

2. Anxiety is a diffuse and vague sense of 
apprehension associated with feelings of uncertainty and helplessness. It is an emotion without a specific object, is subjectively experienced and is communicated interpersonally. It occurs as the result of a threat to the person's well-being, self-esteem, or identity (stuart \& Sundeen, 1983, p. 972).

3. AIDS is the acronym for Acquired Immune Deficiency Syndrome, an incurable disease that destroys the body's immune system leaving its victims vulnerable to cancers and other infections. Evidence indicates that AIDS is transmitted through sexual contact, sharing infected intravenous needles, and, rarely, through the transfusion of blood products. Transplacental transfer occurs, infecting the newborns of infected mothers $50 \%$ of the time (Benenson, 1985, pp. 2-5)

4. Semantic conditioning is a form of classical conditioning in which the conditioned and/or unconditioned stimulus is a word, phrase, or sentence (Navarick, 1979, p. 464$)$.

5. State-Trait Anxiety Inventory (STAI) is a self-evaluative questionnaire used to measure perceived anxiety. The 20-item STATE version asks subjects to rate how they feel at the moment on a $0-3$ point Likert-type rating scale (Spielberger, Gorsuch, \& Lushene, 1970).

In this study, the stimuli were the words that comprise much of the acronym for AIDS. Anxiety was the measure of 
stress given on the STAI. Graded exposure for the words was given to the experimental groups, while the control group received synonyms for the same words.

Research Design

For this study, the subjects were asked to read one of four versions of a text describing the need for continued research on classroom lighting. The text served as a ruse and was comprised of three paragraphs in which subjects received 4,8 , or 12 presentations of the key words in deceptive fashion. Afterwards, subjects were asked to fill out the STAI-STATE Anxiety scale as a measure of baseline data.

Subjects were then asked to complete an opinion questionnaire on classroom lighting that actually served to measure attentiveness to the text. Finally, subjects were asked to fill out an additional questionnaire on AIDS. Following this, a debriefing was made for the true intent of the study. The Human Subjects Institutional Review Board of San Jose State University had approved this study for clearance (Appendix C).

Scope and Limitations

This study surveyed the responses of college students to the subject of AIDS in a classroom setting and at one point in time. Caution is, therefore, recommended in generalizing the results to the population at large. According to Steven Lovett (personal communication, 
September 24,1988$)$, a researcher studying the effects of stress on the elderly at a Veterans Administration Hospital, the STATE version of the STAI may not detect the subtle responses for stress and anxiety that may only be detected by more accurate physiological measures such as the Galvanic Skin Response--GSR. Although Dr. Lovett concedes that the GSR is used more often to record stress responses, he advised against its use in this study due to the limited scope of the experiment, and because special expertise is required to interpret such physiological data. 
Chapter 2

CONCEPTUAL FRAMEWORK AND REVIEW OF LITERATURE

Neuman's (1982) health-care systems model provided a conceptual framework which underscores significantly the role that stress plays in the health of an individual. Neuman's total person approach to patient problems is based on the assumption that the person is an open system interacting with the environment and is either in a dynamic state of well being or is experiencing some degree of ill health. The person is viewed as being in constant change or motion, "in reciprocal action with the environment" (p. 9).

Conceptual Framework

Neuman (1982) states that assessment of the person's environment is critical to identifying and understanding the causes of dysfunction and ill health. This theory is broad and encompassing, emphasizing that the environment is both internal and external and that various stressors make up a person's environment. "Environment has been conceptualized as all factors affecting and affected by the system" (p. 9). It is evident that Neuman believes all sources of stress to be important, and she identifies three main categories of stress:

1. Intrapersonal - forces occurring within the inrividual, e.g., conditioned responses.

2. Interpersonal - forces occurring between one or 
more individuals, e.g., role expectations.

3. Extrapersonal - forces occurring outside the individual, e.g., financial circumstances (pp. 14-15).

Neuman's model represents the individual by a number of encircling rings as in a bull's-eye. At the central core lies the basic structure and energy sources crucial for the organism's survival, such as temperature regulation, genetic response factors, and physiological competence (Figure 1). Moving outwardly, the core is protected by flexible Iines of resistance which act as buffers and response mechanisms to inward impinging forces of stress. One example of this is the mobilization of white blood cells to fight infection. The normal line of defense is the outer solid circle and represents the steady state of wellness of the individual. The normal Iine of defense is a product of a person's usual coping patterns within the context of their culture and their past experiences in coping with stress. The outermost broken ring, or flexible line of defense, is a dynamic barrier which also acts as a buffer for preventing stressors from breaking through the solid line of defense (p. 24). Neuman's holistic concept of health, an open-systems approach to understanding illness, and emphasis on stress reduction made her theory a useful tool for further examination of the possible effects of semantic conditioning on anxiety levels. "The identification of stressors and the nature of reaction or possible reaction to them is critical 


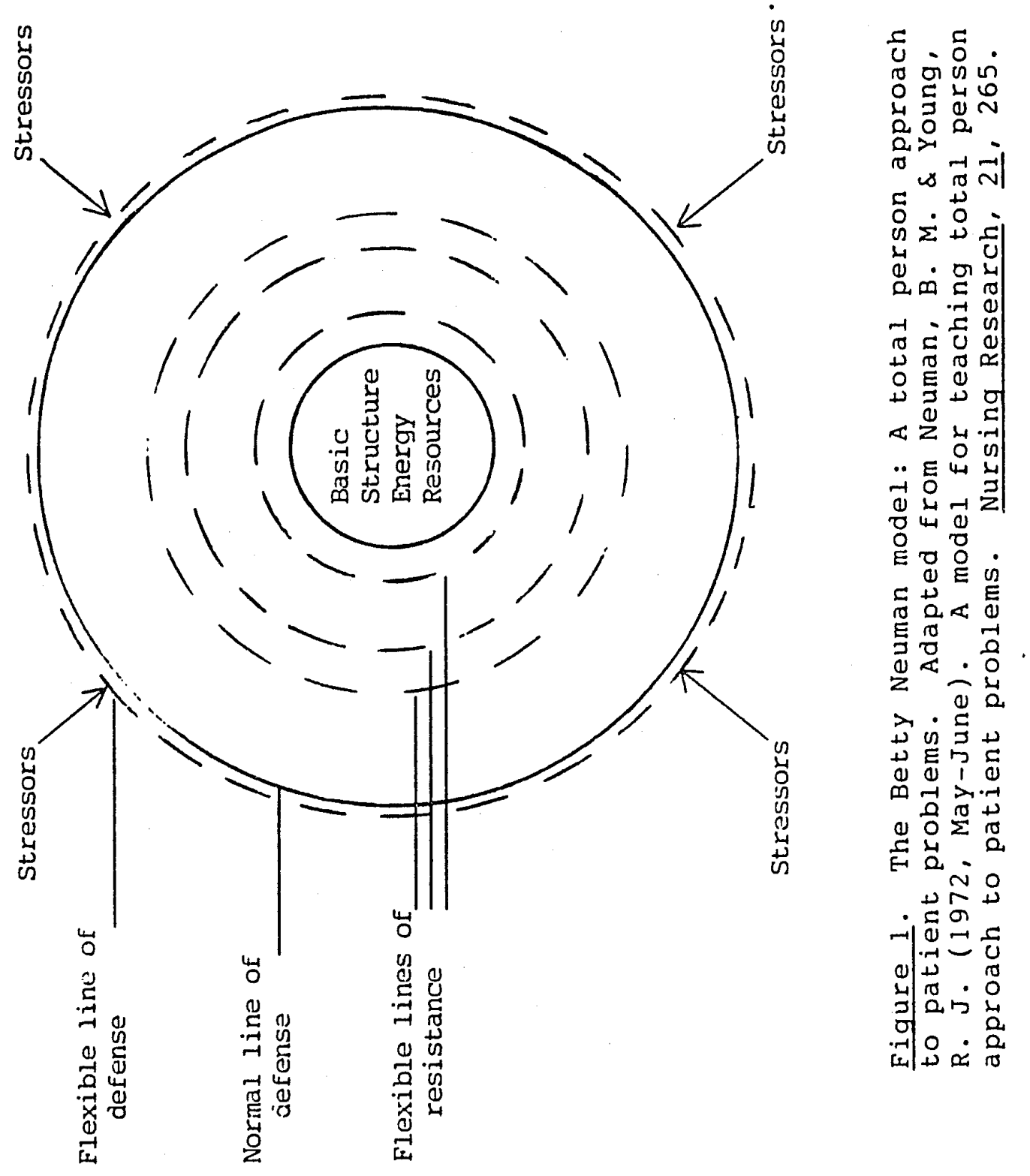


to systems analysis" (p. 9).

Finally, Neuman holds that nursing interventions must be directed towards resolving stress or reconstitution of the individual's normal line of defense. Nursing interventions could be implemented on any of three levels appropriate to the nursing situation:

1. Primary prevention - intervention initiated before or after an encounter with a stressor and emphasizing the strengthening of the flexible line of defense in the presence of stressors.

2. Secondary prevention - interventions initiated after an encounter with a stressor with an emphasis on early case finding and treatment.

3. Tertiary prevention - interventions initiated after treatment with an emphasis on readaptation, reeducation, and maintenance of stability (Riehl \& Roy, 1980, p. 137).

In the context of this study, Neuman's concept of primary prevention was used to identify a potential stressor which was likely to be encountered in the environment. Providing AIDS education would serve the function of strengthening an individual's flexible line of defense if education is found to reduce anxiety or stress in response to the subject of AIDS.

The relationship of the variables (physiological, sociocultural, psychological, and developmental) can affect the degree to which an individual can use a flexible line of 
defense against a potential stressor. Therefore, it is important to strengthen this line of defense to prevent a possible reaction (Marriner, 1986, p. 317).

Review of the Literature

Neuman's (1982) model has been applied and adapted to a variety of therapeutic settings with favorable results. The success of Neuman's conceptual framework is due in part to its broad based assertions about the wellness of the person in the context of the environment. The person is viewed as being in constant interaction with the environment, and healch is a product of an ability to cope with and adapt to stressors which threaten a person's physical, psychological, and physiological performance. These concepts appealed to nursing educators, family therapists, public health educators, and other health care workers.

Neuman's model has been used in the Hospice of Windsor in Ontario as a method of organizing effective multidisciplinary assessments and interventions for patient and family members faced with life-threatening terminal illness (Echlin, 1982). Neuman's conceptual framework was also used successfully by Breckenridge (1982) with renal patients due to its emphasis on prevention. Graff and Graff (1982) adapted the model for use in family therapy for disordered families and reported successful results. While much has been written about the impact of stress on the individual, little research has been conducted on the 
subject of stress and AIDS. Research conducted on AIDS and stress has been mainly confined to those with the disease and caregivers of persons with AIDS. The stigma associated with AIDS was found to increase the psychological stress for lovers of those with AIDS (Geis, Fuller, \& Rush, 1986). These authors equated the disease to a modern-day leprosy, resulting in fear, ignorance, and homophobia. This stigma may have profound implications, as suggested by an earlier study by Cecchi (1984) in that groups affected by AIDS may be immunodeficient as a result of stress associated with a negative self-image and lack of community support.

A later study by Glaser and Gláser (1987) would appear to add credibility to this claim. Their study examined the relationship between stress and the immune function in rats and suggested that stress may impair immunocompetence by altering the DNA repair process. In conjunction with epidemiological studies conducted on distressed populations, distress-related immunosuppression has implications for the elderly and for those with AIDS.

Research has also been conducted on the effects of stress and language behavior. In Peastrel, Wishner, and Kaplan's (1968) study on semantic generalization, the Galvanic Skin Response (GSR) for 96 male subjects was conditioned to a word (the Conditioned stimulus-cs) and tested for generalization to a synonym and homophone for the CS. After repeated pairings with an Unconditioned stimulus 
(UCS), in this case a shock, the synonyms and homophones elicited the same GSR as the original CS.

In a more sociocultural context, Sappington (1976) suggested that semantic conditioning was responsible for increasing prejudicial attitudes of white male subjects who were asked to rate Blacks on a positive versus negative rating scale. A two-way analysis of variance (ANOVA) for experimental groups given the word, "negro," paired with either positive, neutral, or negative words, showed a higher increase in the negative rating for the subjects given the negative words, while the other groups showed no change. Sappington suggested that semantic conditioning in the area of strong emotional import may produce results in an undesired direction.

In other disciplines as well, the significance of stress in the assessment of health-risk factors has received considerable scrutiny. The field of medicine has long regarded stress as an important risk factor for the development of heart disease. A recent study by researchers from Los Angeles and Washington, D.C., demonstrated that mental stress caused episodes of potentially serious blood shortage to the heart muscle in some patients with pre-existing coronary heart disease (Study confirms role, 1988).

As the impact of stress on the health of individuals is becoming more apparent, stress management has become a 
discipline unto itself. Education on stress reduction for cardiac rehabilitation patients and patients with other stress-related disorders involve counseling on proper nutrition, aerobic exercise, relaxation techniques, and identifying personal stressors (Stanhope \& Lancaster, 1984). The literature review reflects that stress has become an important subject of investigation both in theory development and in practice. Factors that create stress may vary in each society. Yet, it would be accurate to state that in American society, stress is believed to play a significant role in the development of certain illnesses, such as heart disease, peptic ulcer, and colon disease, and a myriad of psychological disorders. Given this information, the issue of stress relative to the disease of AIDS warranted further investigation. 


\section{Chapter 3 \\ METHODOLOGY \\ Research Design}

A pilot study was implemented to determine if people's level of anxiety was heightened unknowingly in response to the frequency of exposure to words, Acquired, Immune, Aids, and Deficiency, and if knowiedge about AIDS had any relationship to this anxiety. This study used a single factor masked-study design to assess subjects' response to these words. The advantage of the masked design format was to eliminate subject bias or favorable conscious responses. that might be incurred in a study involving a volatile issue such as AIDS. In addition, this format would assess the effects on anxiety given the degree of exposure to the words.

The single dependent variable in this study was the measure for anxiety as represented on the STATE version of the State-Trait Anxiety Inventory authored by Spielberger (1970). Two other measures were those for attentiveness to the text and subjects' knowledge about AIDS. The independent variable, or treatment, in this study was the frequency of presentation of the key words in material read by the subjects. Subjects were randomly assigned to one of three experimental groups or a control group that was given synonyms in place of the key words. 
Sample and setting

The sample group consisted of 53 volunteer participants out of a total of 81 college students who had volunteered to take part in the study as one means of acquiring extra credit for a course. Of the 81 students who volunteered, 58 students actually showed up to participate in the study. From these 58 students, 53 elected to remain in the study after the debriefing. All participants were students enrolled in a general psychology course at a northern California state university. Twenty-two subjects were male, with a mean age of 19.4 years, and 31 subjects were female, for which the mean age was 19.9 years. The age range for all subjects was from 18 to 42 years old. The setting for data collection was a large lecture hall where the students normally had class once a week.

Instrument

This study utilized the STATE version of the State-Trait Anxiety Inventory (STAI) developed by Spielberger, Gorsuch, and Lushene (1970). The scale is published by Consulting Psychologists Press in Palo Alto, California, and is available for public use. Use of the scale was suggested by Dr. Steven Lovett of the Veterans Administration Hospital in Palo Alto, California. The self-evaluation questionnaire is composed of 20 questions which require the subject to indicate how he/she feels "right now, that is, at this particular moment." The 
subject responds to each item indicating the intensity of his or her feelings on a four-point rating scale. The STAI has been widely used and accepted as a useful tool in studies measuring anxiety levels (Tullman, Tullman, Rogers, \& Rosen, 1979). In addition to the STAI, each packet contained the following:

1. Title sheet.

2. Consent form to participate in a study on classroom lighting.

3. A sheet entitled student Opinion Survey on Classroom Lighting.

4. A sheet entitled Survey Form on Classroom Lighting.

5. A sheet entitled Knowledge Survey on AIDS.

6. Informed consent form to participate in a study entitled The Effects of the Words, Acquired, Immune, Aids and Deficiency, on Students' Perceived Anxiety.

Four versions of the text entitled student Opinion Survey on Classroom Lighting were devised offering $0,4,8$, and 12 presentations of the key words in deceptive fashion - (Appendix B). The text served as a ruse; subjects thought they were reading a commentary underscoring the importance of their opinions on classroom lighting as a contribution to continued research on optimal illumination levels. However, the text served only as a backdrop on which to impose the key words.

The Survey Form on Classroom Iighting consisted of 13 
questions, 5 of which asked subjects about specific facts mentioned in the text. These 5 questions served to measure attentiveness to the text displaying the key words. Finally, the Knowledge Survey on AIDS was composed of 10 questions measuring general knowledge about AIDS as commonly presented by the media, AIDS education workshops, and the Surgeon General's Report on AIDS (Koop, 1986).

Data Collection Method

Permission to conduct the pilot study was granted by the Human Subjects Institutional Review Board of San Jose State University (Appendix C). Students who wished to participate in the study were asked to register on a sign-up sheet. Students were only told that the study required them to fill out a survey scale on classroom lighting. Subjects arrived promptly on the data collection day. A roll call was quickly taken, and students were asked to come forward and pick up a survey packet from either of two front tables. After receiving their packets, subjects were instructed not to open them, but to return to their seats and await further instructions from the investigator.

The survey packet which each subject received was color coded for the different groupings. Students receiving the control version were given synonyms for the key words. Students in the low exposure group were presented with the four key words in the first paragraph only. Subjects in the moderate exposure group received the four words in the first 
and second paragraphs. Finally, students in the high exposure group were given the four words in all three paragraphs.

All packets were evenly mixed (alternating colors) and placed face down on the two tables from which subjects were asked to come forward and obtain them. This assured random distribution of all four versions. After being informed that the researcher was conducting a survey of their opinions on classroom lighting, subjects were instructed to fill in their age and sex on their title sheets, turn the page, and read and sign the consent to participate in the study on classroom lighting. Subjects were told never to proceed to the next page without first being instructed to do so. After the consent was signed by all the subjects, they were instructed to read carefully the one page text, which offered varied presentations of the key words. Next, subjects were asked to complete the STATE version of the STAI. This was presented as a mood scale necessary for obtaining baseline data important to any study. After filling out the STAI, subjects were asked to complete the Survey Form on Classroom Lighting. When subjects had completed this form, they were told that this completed the survey on classroom lighting.

In keeping with the masked-study design of the experiment, the investigator then asked the subjects to fill out one more additional questionnaire which sought to survey 
their knowledge about AIDS. This was suggested as a favor to a colleague who was said to be conducting a study on students' knowledge on AIDS and as being completely separate from the survey on classroom lighting. After completing this questionnaire, students were then told that the true intent for their participation was to determine if they evidenced any anxiety in response to the words that comprise much of the acronym for AIDS, and whether their knowledge about AIDS had any relationship to this amount of anxiety. After debriefing, subjects were asked to read carefully and sign the informed consent sheet if they wished to remain in the study. This completed the experiment, which took approximately 34 minutes.

This study was designed with the assistance of Dr. Steven Lovett and the recommendations of Dr. Larry Thompson of the Veterans Administration, Palo Alto (California) Division. Significant findings and analysis of the data are presented in the following chapter. 


\section{Chapter 4 \\ ANALYSIS AND INTERPRETATION OF DATA}

The purpose of this study was to explore the effect of exposure to the words, Acquired, Immune, Aids, and Deficiency, on subjects' perceived anxiety and determine whether knowledge about AIDS had any relationship to this level of anxiety. The study group consisted of 53 subjects, 22 males and 31 females. The subjects were all university students.

\section{Data Collection and Analysis}

After the experiment was conducted, survey packets were collected and separated by group. The researcher hand scored the responses of all subjects on the state-Trait Anxiety Inventory (STAI), the survey sheet used to measure attentiveness and the questionnaire on AIDS knowledge. Responses on the 20-item STAI (Appendix B) ranged from "not at all" to "very much so" and were given a value of $0,1,2$, and 3, respectively. The scoring was reversed for questions indicating low anxiety; these were items 1, 2, 5, 8, 10, 11, 15, 16, 19, and 20. Higher total scores on the STAI reflected higher levels of STATE anxiety.

Questions $2,5,8,11$, and 13 were used to assess attentiveness to the text on the 13-item survey Form on Classroom Lighting (Appendix B). A "Yes" response was correct for item 11 while a "No" response was correct for 
items $2,5,8$, and 13 . The total number of correct responses on these questions was assumed to reflect greater attentiveness to the text incorporating the key words. On the 10-item Knowledge Survey on AIDS (Appendix B), subjects were given the option to agree or disagree with 10 numbered statements about AIDS. For items 1, 2, 3, 4, and 10, the correct response was "Agree." For the remaining items, the correct response was "Disagree." The total number of correct responses indicated greater knowledge about AIDS.

For statistical analysis, the 4 groups were numbered 1 through 4. A one-way analysis of variance was used to examine mean differences between groups for the measures of anxiety, attentiveness to the text, and AIDS knowledge, with a probability level (alpha) set at the .05 level. A Pearson's product moment coefficient was also used to determine the relationship between the three dependent variables. The statistical analysis was conducted using an SPSS-Version 2 IBM computer. Individual scores were combined and used for group analysis of the sum of squares (SS), degrees of freedom ( $\underline{\mathrm{df}})$, Mean Square (MS), F Ratio (f), and probability value (p), with an alpha level of .05 set for significance. The analysis of variance conducted on the STAI, Attentiveness and AIDS Knowledge scores yielded no significant differences between groups (Table 1). 
Table 1

ANOVA Summary Table Comparing Group Differences for STAI, Attentiveness, and AIDS Knowledge scores

\begin{tabular}{lrrrrr}
\hline \multicolumn{1}{c}{ Variable } & $\underline{\text { SS }}$ & $\underline{\text { df }}$ & $\underline{\text { MS }}$ & $\underline{f}$ & $\underline{p}$ \\
\hline STAI & 106.96 & 3 & 35.65 & .522 & .669 \\
Attentiveness & 1.44 & 3 & .48 & .992 & .404 \\
AIDS Knowledge & 5.58 & 3 & 1.86 & 1.117 & .351 \\
\hline
\end{tabular}

However, Pearson product moment coefficients revealed a significant negative correlation between each participant's STAI score and AIDS knowledge score (Table 2). Higher scores on the survey of AIDS knowledge were associated with lower scores on the STAI, $\underline{r}=-.299, \underline{p}<.05$.

Table 2

Intercorrelation Among STAI Scores, AIDS Knowledge, and Attentiveness

\begin{tabular}{lccc}
\hline & STAI & AIDS Knowledge & Attentiveness \\
\hline STAI & 1.00000 & & \\
AIDS Knowledge & $-.29903^{*}$ & 1.00000 & 1.00000 \\
ATTENTIVENESS & -.22761 & -.09700 & \\
\hline * $\underline{\underline{P}} .05$. & & & \\
\hline
\end{tabular}


In summary, this study demonstrated that there was no significant effect for the level of exposure to the key words on subjerts' perceived anxiety as measured on the STAI. Attentiveness to the text and knowledge about AIDS were not significantly different between groups. A negative relationship was demonstrated between individual scores on the STAI and the AIDS knowledge survey, $\underline{r}=-.299$; subjects scoring higher on the knowledge survey scored lower on their STAI. Conclusions and recommendation from this study will be presented in Chapter 5 . 
Chapter 5

CONCLUSIONS AND RECOMMENDATIONS

The purpose of this study was to investigate the undercurrent effect for anxiety in response to the subject of AIDS and to determine if knowledge about AIDS had any relationship to this level of anxiety. Neuman's health care systems model served as the conceptual framework for this study. Neuman believes that stress plays a significant role in the health functioning of the individual. Neuman's coricept of primary prevention was undertaken in an effort to identify a potential stressor that was possibly encountered in the environment. That stressor was the subject of AIDS. Additionally, it was believed that by demonstrating an undercurrent of anxiety to the subject of AIDS, an argument might be made that every member of society is affected to some extent by the disease. Therefore, education about AIDS might be the best means of lessening the effect of this stressor, thereby enhancing the health functioning of the individual.

\section{Conclusions}

This study used a non-directional hypothesis for the undercurrent effect for AIDS, the question being whether an undercurrent of anxiety towards the subject of AIDS existed at all. Given the measure used to gauge perceived anxiety, no significant increase in anxiety in response to the 
potential stressor was demonstrated.

However, the lack of statistical support for such an undercurrent effect does not necessarily discount the possibility that anxiety exists in response to the subject of AIDS. It may be that such anxiety can only be identified by more sensitive instruments that would register more accurately the subtle physiological effects of anxiety, such as the Galvanic Skin Response. Other objective means of determining an increase in stress or apprehension to the matter of AIDS, such as blood pressure and heart rate, may also be indicated.

The significant negative correlation between anxiety and AIDS knowledge demonstrated in this study also warrants mention. As with any correlational study, no cause and effect relationship can be explicated or supported. Still, it is interesting to note that past studies, such as the O'Donnells' research on AIDS in-service education, indicated that knowledge about AIDS decreased stress and anxiety for involved caregivers. Given the prevalent concern over the issue of AIDS in the population tested, it may be reasonable to assume that an undercurrent effect for anxiety might exist and that this level of anxiety is dependent on the type of knowledge individuals possess about AIDS. For example, accurate knowledge about how AIDS is transmitted may serve to decrease anxiety in response to the subject of AIDS, while concern over the prevalence of the disease in 
society might increase this anxiety. It is suggested that specific forms of knowledge may have different effects on anxiety about AIDS.

Finally, in examining the information from this study, the sample size and means of assessing anxiety must be considered. The small sample size of the experimental groups and the large within-group variance on the STAI scores make it difficult to detect differences between groups.

\section{Recommendations}

The following recommendations are made based on the . findings of this study:

1. This study should be repeated using more objective and sensitive measures for the subtle effects of anxiety in response to the subject of AIDS. It is suggested that subjects' response for anxiety be assessed by both cognitive tools, such as the STAI, and by physiologic measures as well.

2. Future studies using a multiple group, experimental design should acquire a larger total sample population for better statistical comparison of the mean group effect for the independent variable.

3. Question number two on the attentiveness scale should be rephrased or eliminated and replaced with another question to lessen ambiguity.

4. Future studies should include the ethnic make-up 
for the sample population to determine if the wording of the STAI and incorporated scales are universally meaningful to all involved subjects.

5. Finally, a repeat study should attempt to distinguish between types of information about AIDS that are believed to be anxiety provoking or anxiety suppressing. Two questionnaires can be developed to identify positive versus negative forms of AIDS knowledge and correlated with subjects' responses on the STAI.

The STAI is only one means of assessing anxiety levels in response to a potential stressor on the cognitive level. Other scales have been developed to assess for stress and anxiety that may be more suitable for assessment of the independent variable studied. This study attempted to determine if an undercurrent effect for anxiety existed via the process of semantic conditioning to the words, Acquired, Immune, Aids, and Deficiency, as measured by the STAI. Further, existing knowledge about AIDS was examined to determine if knowledge level correlated inversely with subjects' responses to the independent variable. Although the results of this study do not support such an effect for semantic conditioning, knowledge level did reflect a significant, negative correlation to responses on the STAI. Further study is suggested to determine if a conditioned effect exists in response to the concept of AIDS and how knowledge about AIDS affects such responses. 
REFERENCES 
References

Baron, R. A., \& Byrne, D. (1977). Social psychology: Understanding human interaction. Boston: Allyn and Bacon.

Benenson, A. S. (1985). Control of communicable diseases in man. Springfield, VA: John D. Lucas Printing. Breckenridge, D. M. (1982). Adaptation of the Neuman's systems model for the renal client. In A. Marriner, Nursing theorists and their work (p. 322). St. Louis: C. V. Mosby.

Cecchi, R. L. (1984). Stress: Prodrome to immune deficiency. Annals of the New York Academy of Sciences, 437, 286-289.

Centers for Disease Control (1988). AIDS weekly surveillance report. Atlanta, GA: United States AIDS Program, Center for Infectious Diseases.

Echlin, J. D. (1982). Palliative care and the Neuman model. In A. Marriner, Nursing theorists and their work (p. 322). St. Louis: C. V. Mosby. Geis, S. B., Fuller, L., \& Rush, J. (1986). Lovers of AIDS victims: Psychological stresses and counseling needs. University of Colorado - Denver Death Studies, 10, 43-53. Glaser, K., \& Glaser, R. (1987). Psychosocial moderators of immune function. Annals of Behavioral Medicine, 9 , $16-20$ 
Graff, J. D., \& Graff, H. (1982). The Neuman model adapted

to family therapy. In A. Marriner, Nursing theorists and their work (p. 322). St. Louis: C. V. Mosby. Horovitz, B. (1988, March). AIDS crisis hits diet candy hard. Los Angeles Times, pp. 1, 5 .

Koop, C. E. (1986). Surgeon general's report on AIDS. U.S. Department of Health and Human Services. Mann, J., Chin, J., Piot, P., \& Quinn, T. (1988, October).

The international epidemiology of AIDS. Scientific American, p. 82 .

Marriner, A. (1986). Nursing theorists and their work. St. Louis: C. V. Mosby. Navarick, D. J. (1979). Principles of learning: From

laboratory to field. Reading, MA: Addison-Wesley. Neuman, B. (1982). The Neuman systems model: Application to nursing education and practice. Norwalk, CT: Appleton-Century-Crofts. Neuman, B., \& Young, R. J. (1972). A model for teaching total person approach to patient problems. Nursing

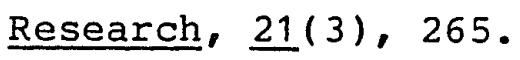

O'Donnell, L., \& O'Donnell, C. (1987). Hospital workers and AIDS: Effect of in-service education on knowledge and perceived risks and stresses. New York State Journal of Medicine, $87,278-280$.

Osgood, C. E. (1965). The measurement of meaning. Urbana, IL: University of IIlinois Press. 
Peastrel, A., Wishner, J., \& Kaplan, E. (1968). Set, stress and efficiency of semantic generalization. Journal of Experimental Psychology, 77(1), 116-124.

Riehl, J., \& Roy, C. (1980). Conceptual models for nursing practice. Norwalk, CT: Appleton-Century-Crofts. Sappington, A. A. (1976). Application of semantic desensitization in an area of strong emotional significance. Perceptual and Motor Skills, $43(1), 310$. Spielberger, C. D., Gorsuch, R. L., \& Lushene, R. E. (1970). Manual for the state-trait anxiety inventory (selfevaluation questionnaire). Palo Alto, CA: Consulting Psychologists Press. Stanhope, M., \& Lancaster, J. (1984). Community health nursing. St. Iouis: C. V. Mosby. Stearns, F. R. (1972). Anger: Psychology, physiology, pathology. Springfield, IL: Charles C. Thomas. Stuart, G., \& Sundeen, S. (1983). Principles and practice of psychiatric nursing. St. Louis: C. V. Mosby. study confirms role of stress in heart attacks. (1988, Apri1). San Jose Mercury News, p. 12. Tullman, G., Tullman, M., Rogers, B., \& Rosen, J. (1979). Anxiety in dental patients: A study of three phases of state anxiety in three treatment groups. Psychological Reports, $45,407-412$. 
APPENDIX A

Newspaper Clipping 


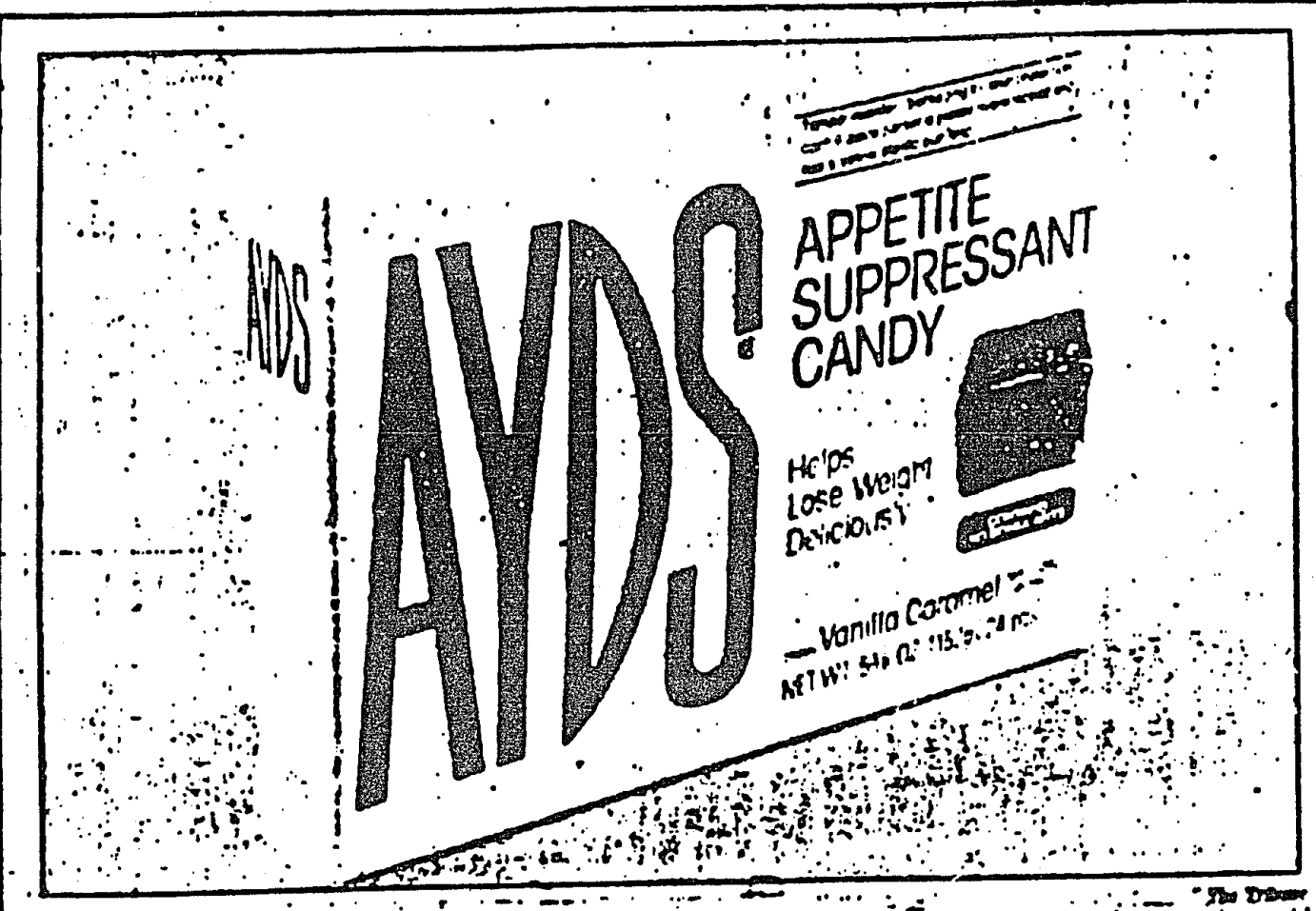

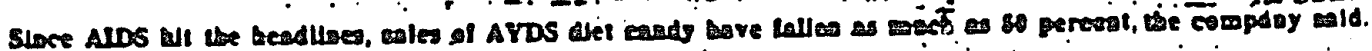

\section{AIDS crisis hits Ayds diet candy hard}

\section{Company thinks it bas answer in new asme: Agdslim; experts arents so sure}

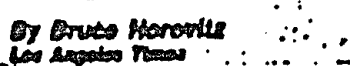

LOS ANGEM DS - AYds, the diet eaody desperately in earck of a name, thinlo th may have found a ow ope - Aydulim.

That is the name being leat. marbeted for the appeute ooppresant bedeviled by a ane thai sounda like the deadly ATDS iring.

"We bope this takes the carze ofl of It $^{-1}$ eald Robert Rerglass, chalrmas of Dep Corpn the 109 Angeles tonoufocture that aloo colkes ooch lamlliar coesames products as invorls moabrash and ropol toothparte hlle nost at Dep's atber product have soces cales time oret the pant fev geara. coles of Agos have plumaneted as ruch as $B 0$ parcept ald.

sven thongt eales of Agte are oll. It to a proflt-maker for the compapy, Borglaes add. Ayds' cirritul comal sales of about 77 Enlllios, nowever. are about half of vation bey ore guring the product's regiday is the ourly 1980s, Berdass vald

And evea though Agds soam to De garmering s lot of media atteo. ther il account for aoly trac. cos of Dep's, arounal alea of $\$ 86$. millior tais la a conall pobleso mita a gianue prome." ara Ber-

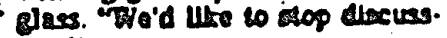
tang $\mathrm{It}$

T2er Hme I ret a phowe call Irom someone." Berplas sold. they end the coaveralion with the arme cuestloa: By the vay. did gou oolve the Aydo aame moblem ret?"

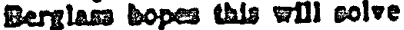
IL But ocveral marteling experts save thelr coubes.

"L Mins It's onto move," and Carlos 5 armar. pal.

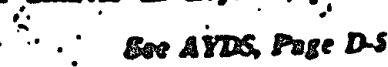




\section{APPENDIX B}

Survey Packet on Classroom Lighting 
AGE

$\operatorname{sex} M-/ F$

SORVEY PACRET ON

CLASSROOH LIGKTING 
CONSENT TO PARTICIPATE

IN RESEARCH

INVESTIGATOR: JOhn WOOdY

PROJECT: Student Survey on Classroom Lighting

MY SIGNATURE ON THIS CONSENT PORM INDICATES THAT I HAVE AGREED TO PARTICIPATE IN STUDENT RESEARCH AS A CONDITION OF ACQUIRING EXTRA CREDIT. I ACKNOWLEDGE THAT I HAVE THE OPTION TO PARTICIPATE IN OTHER PROJECTS BESIDES MR. WOODY'S STUDY FOR EXTRA CREDIT, AND THAT I MAY WITHDRAW FROM THIS STUDY AT ANY TIME. I HEREBY ALLOW MY PERMISSION TO PARTICIPATE, FREELY AND WITHOUT COERCION, IN THIS STUDY. 


\section{Student Opinion Survey}

on Classroom Lighting

Do you believe that you are exempt from the effects of poor lighting? Do you feel that the present lighting assists, Impedes or has no effect on your classroom performance? A shortcoming exists in the obtalned literature on the subject. Here, you w111 have an opportunity to give your views on the $18 s u e$.

The collected body of research into what constitutes "optimal lighting" appears scant. This inadequacy or neglect in recent interest is most apparent, in that the latest definitive study on optimal 111 umination levels dates back to 1973. Since students spend considerable time in artificially lighted indoor environments, your thoughts on the subject are important, and may provide useful tips relative to future research. On-going research is necessary, as no one is free from the influences of their environment.

Could better lighting be gained with the increased use of natural sunlight? Would soft lighting. in your opinion, enhance task performance over neon llghting? Could added assistance be achieved with separate desk-top lamps? Help us compensate for the current lack in research. Afterall, if we can never be free or exempt to what takes place around us, then we should have something to say about it. Thank you for your participation! 


\section{student Opinion Survey}

on classroom lighting

Do you believe that you are immune to the effects of poor lighting? Do you feel that the present lighting aids. Impedes or has no effect on your classroom performance? A deficiency exists in the acquired literature on the subject. Here, you will have an opportunity to give your views on the issue.

The collected body of research into what constitutes "optimal lighting" appears scant. This inadequacy or neglect in recent interest is most apparent, in that the latest definitive study on optimal illumination levels dates back to 1973. Since students spend considerable time in artificially lighted indoor environments, your thoughts on the subject are important, and may provide useful tips relative to future research. On-going research is necessary, as no one 1s free from the influences of their environment.

Could better lighting be gained with the increased use of natural sunlight? Would soft lighting, In your opinion. enhance task performance over neon lighting? Could added assistance be achleved with separate desk-top lamps? Help us compensate for the current lack in research. Afterall, if we can never be free or exempt to what takes place around us, then we should have something to say about it. Thank you for your participation! 
student opinion survey

on Classroom lighting

Do you believe that you are immune to the effects of poor lighting? Do you feel that the present lighting aids, impedes or has no effect on your classroom performance? A deficiency exists in the acquired 11terature on the subject. Here, you yill have an opportunity to give your views on the issue.

The acquired body of research into what constitutes "optimal lighting" appears scant. This deficiency or neglect in recent interest is most apparent. in that the latest definitive study on optimal 111 umination levels dates back to 1973. Since students spend considerable time in artificially lighted indoor environments, your thoughts on the subject are important, and may provide useful alds relative to future research. On-going research is necessary, as no one is immune to the influences of their environment.

could better lighting be gained with the increased use of natural sunlight? Would soft lighting, in your opinion, enhance task performance over neon lighting? Could added assistance be achleved with separate desk-top lamps? Help us compensate for the current lack in research. Afterall, 1f we can never be iree or exempt to what takes place around us, then we should have something to say bout 1 t. Thank you for your participation! 


\section{student opinton survey}

on classroom lighting

Do you believe that you are immune to the effects of poor lighting? Do you feel that the present lighting alds, impedes or has no effect on your classroom performance?

A deflelency exista in the acquired literature on the subject. Here, you will have on opportunity to give your vieus on the 1ssue.

The acquired body of research into that constitutes "optimal lighting" appears Bcant. This deficlency or neglect in recent interest is most apparent, in that the latest definitive study on optimal illumination levels dates back to 1973. Since students spend considerable time in artificially lighted indoor environments, your thoughts on the subject are important, and may provide useful aids relative to future research. On-going research is necissary, as no one is immune to the influences of their environment. Could better lighting be acquired with the increased use of natural sunlight? Would soft lighting, In your opinion, enhance task performance over neon llghting? Could additional aids be achieved with the use of separate desk-top lamps? Help us compensate for the current deficiency in the research. Afterall, if te can never be Iree or immune to what takes place around us, then ye should have omething to say about it. Thank you for your participation! 
Self-Evajuation Questionnaire

\begin{abstract}
A numbri of statements which people have used to descrilie thellisclves are gjuen below. read each statement and then wilt a clieck nark ( ) on the apfropriate dine to the right of the statement to indicate how jou feel rjyht not, that is, at this moment. There ore no right or wrong anskers. no not sfend too much time on any one staterent but give the onswer which seens to describe your present Eeelings best.
\end{abstract}

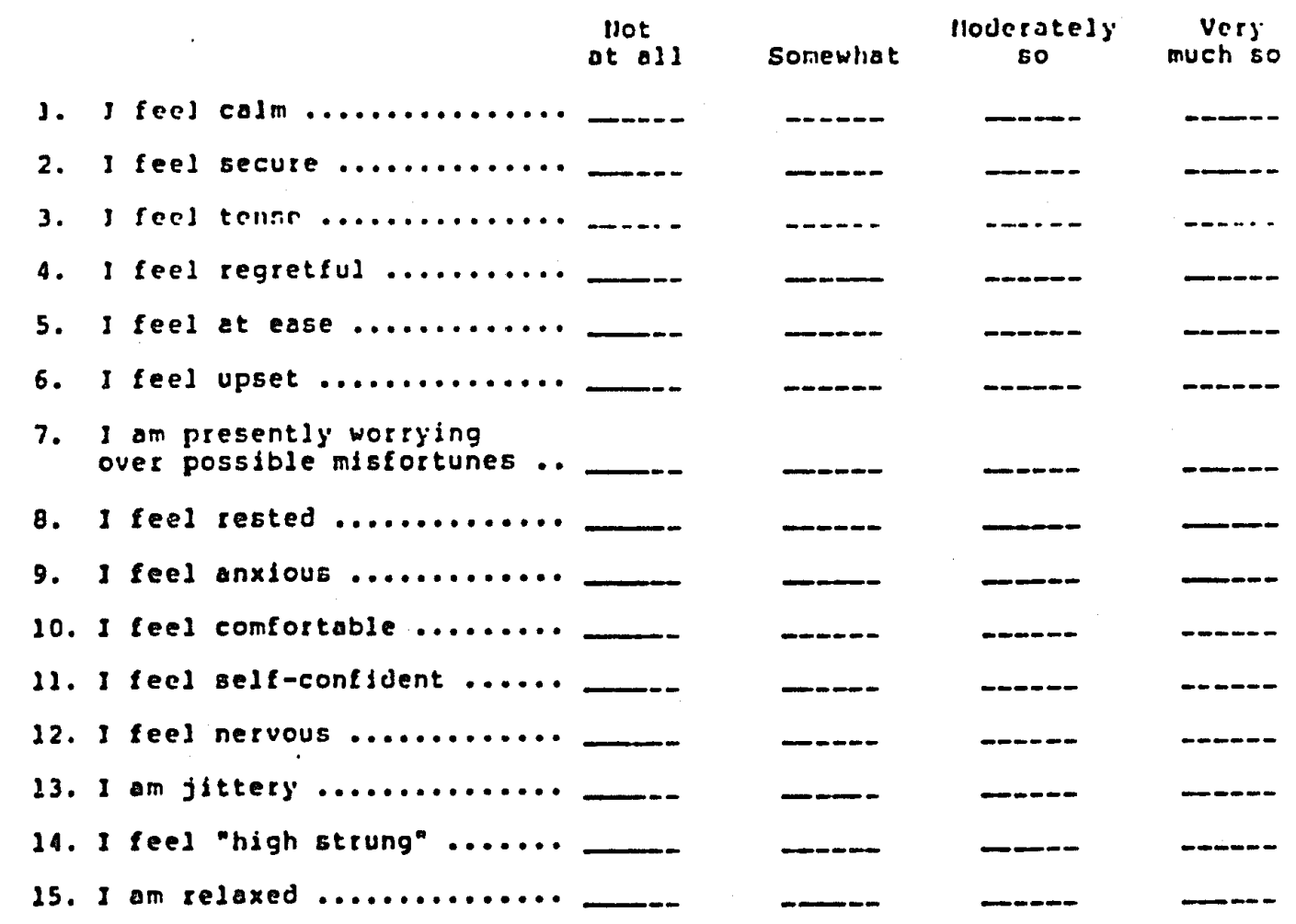

(continued on next page) 
Sej f-rvajuation Questionnaire, P. 2

$\begin{array}{lcc}1101 & \text { lloderately verj } \\ \text { at asl sonewliat } & \text { so } & \text { much so }\end{array}$

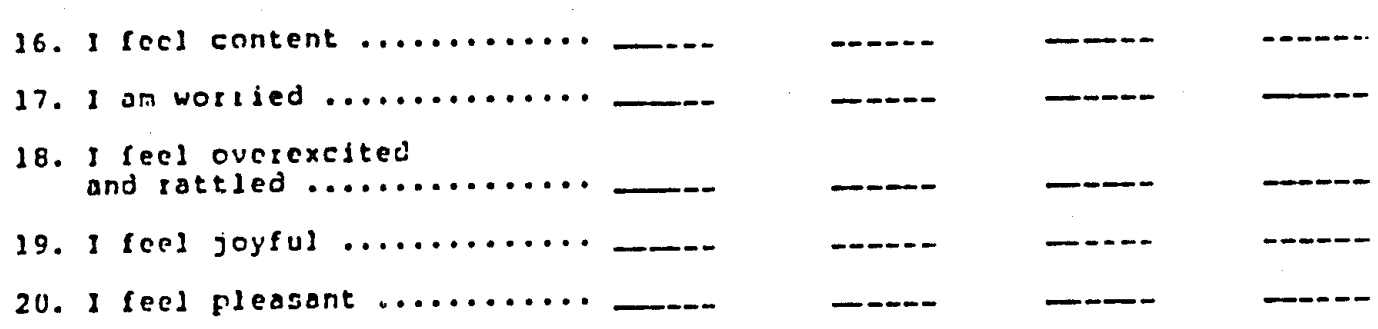


SURVEY FORM ON CLASSROOM LIGHTING

THIS CHECK-OFF SHEET WILL REFLECT BOTH YOUR OPINIONS AND YOUR MEMORY. CHECK (V) EACH STATEMENT INDICATING WHETHER OR NOT YOU AGREE WITH IT. DO NOT TURN BACK TO THE YELLOW PAGE.

YES/NO

1. I fiel that the present lighting is dequate-...- -

2. "Outdoor" lighting yas mentloned on the yellow shiet-_.-_-

3. Brains, not lighting, determine task performance-- - -

4. I don't really care about the issue-c-

5. The yellow sheet mentioned the year 1972--

6. Research money would best be spent in other areas that, in my opinion, are more important-......

7. I vould perform better with brighter lighting-...- -

8. The yellor shrist failed to mention "optinal ildumination levels"

9. Good or proper lighting is relative to one's eyesight-.....

10. Further research is needed and yould be useful-..- - -

11. Natural sinight was mentioned on the yelloy sheet-D-

12. Students ghould have the ginal say as to that constituter the best lighting-.-

13. The yellou sheet failed to wention neon lighting-- _- 
KNOWLEDGE SURVEY ON AIDS

INDICATE WHETHER YOU AGREE OR DISAGREE WITH THE FOLLOWING STATEHENTS ABOUT AIDS BY PLACING: A CHECK (V). MARK IN THE APPROPRIATE COLUMN. ANSWER ALL ITEMS $1-10$.

1. AIDS is a disease that cripples the immune system--

2. AIDS 18 caused by virus-0.- ve-

3. At present, there is no kroun cure gor AIDS-

4. AIDS is considered epidemic in the U.S.-.--

5. AIDS is knoun to only infect homosexuals, intravenous (IV) drug abusers. people who donate blood and hemophiliacsmmon

6. AIDS can be spread by casuad contact-...--

7. If you use a condom, you cannot get AIDS---

8. AIDS is cauged by a bacteris uth an affindty for homosexua18. bloexuala. IV drug abusers. prostltutes, hemophiliacs and those ulth nultiple bex partners-0.

9. Heterosexuals have a natural immunity agoinst

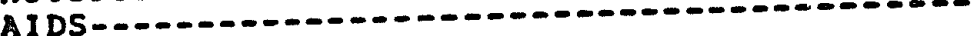

10. AIDS is a "blind virus" that can be acquired by anyone under the rlght conditions. You do not have to be homosexual or IV drug abuser to get AIDS. 
AGREEMENT TO PARTICIPATE IN RESEARCH AT SAN JOSE STATE UNIVERSITY

RESPONSIBLE INVESTIGATOR: JOHN WOODY

TITLE OF PROTOCOL: THE EFFECTS OF THE WORDS ACQUIRED, IMMUNE, AIDS AND DEFICIENCY ON STUDENTS PERCEIVED ANXIETY

I have been asked to participate in a research study investigating the effect that semantic conditioning has on anxiety, and the relationsinip of knowledge about AIDS to this level of anxiety. I have been debriefed as to the true intent for Mr. Woody's study. My signature on the following page indicates that I wish to remain a participant in this project for AIDS research.

I understand that

1). There are no anticipated risks to participating in this study.

2) The possible benefits to my participating in this project may be that information I provide might contribute to increased understanding about AIDS and anxiety, ano may further underscore the relevance that preventive health education may have on decreasing fears about AIDS.

3) There are no other satisfactory means or methods of testing available at this time, apart from the masked-study designed employed in this project.

4) The results of this study may be published, but any information as to my identity or participation in this study will remain strictly confidential.

5) Any questions about my participation in this study will be answered by John Woody (408) 971-9329. Complaints about the procedures may be presented to Dr. Virgil Parsons, Faculty Chair for the Department of Nursing, Ph. (408) 924-3130. For questions or complaints about research subject's rights, or in the event of a research-related injury, contact Serena Stanford, Ph. D. (Associate Academic Vice President for Graduate Studies) at (408) 924-2480.

6) My consent is given freely without being coerced; I may refuse to participate in this study or in any part of this study, and I may withdraw at any time without prejudice to my relations with sJSU.

7) If requested, I will receive a copy of this consent form for my file. 
I HAVE MADE A DECISION WHETHER OR NOT TO PARTICIPATE. MY SIGNATURE INDICATES THAT I HAVE READ THE INFORMATION PROVIDED ABOVE AND THAT I HAVE DECIDED TO PARTICIPATE. 
APPENDIX C

Permission to Conduct Study 


\section{HUMAN SUBJECTS INSTITUTIONAL REVIEW BOARD PAOJECT PROPOSAL REVIEW}

1. the undersigned member of the San Jose State University Human Subjects Institutional Review Board, have roviewed the following proposal submittod to the Committio on 11/15/88 by:

PRINCIPAL INVESTIGATOR: John Hoody

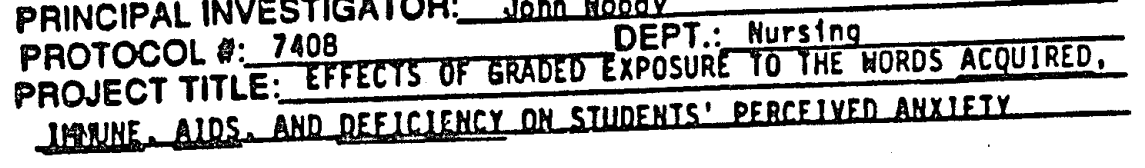

I recommend the following action (indicate one):

1. Approved fer cloaranco as Involving minimal risk to Human Subjects.

2

2. Approved for clarance with risk to Human Subjacts.

3. Approved lor ctearance when the following conditions are mol:

4. Nol Approved (rolurn to principal investigator for following reasons):

5. Expodited Reviow (spocify condition[s] that marit axpodited roviow):

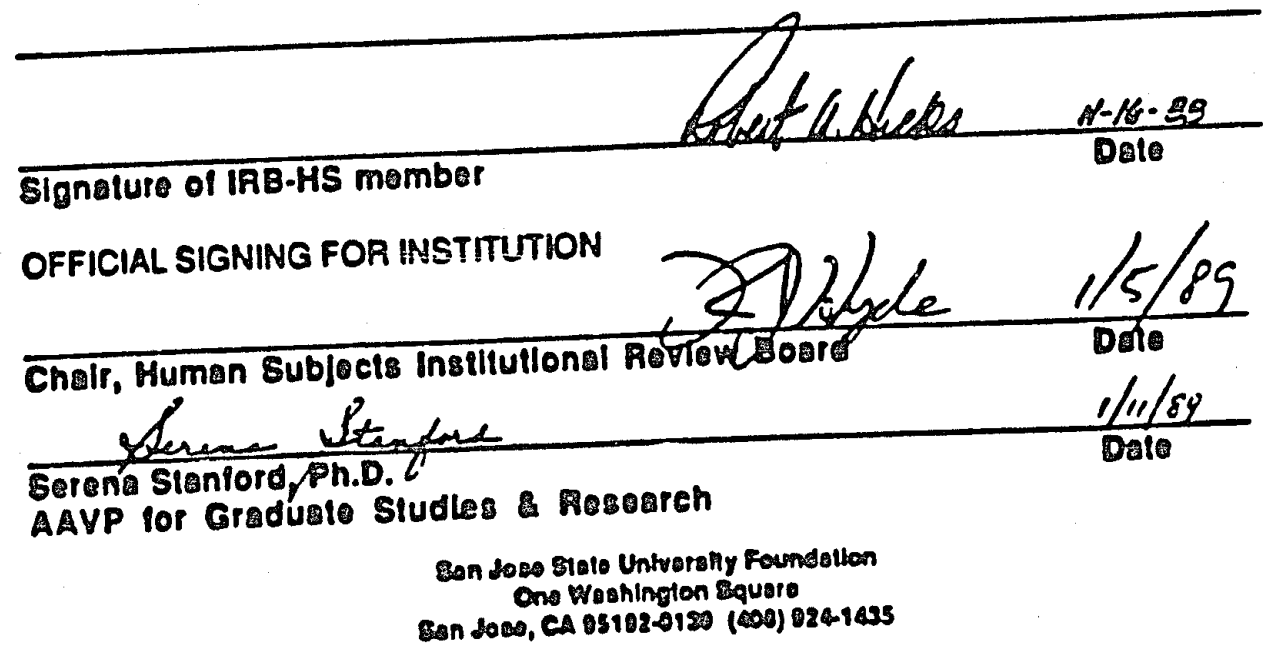




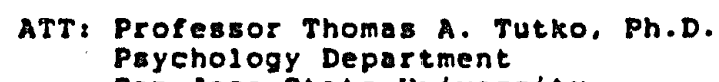

RE: STUDENT SUBJECT POPULATION

THIS FORM IS A LETTER OF CONSENT INDICATING THAT I HAVE GIVEN JOHN HOODY PERMISSION TO USE MY STUDENTS AS SUBJECTS IN HIS PROPOSED EXPERIMENTAL RESEARCH PRCJECT. I UNDERSTAND THAT ALL STUDENT PARTICIPATION WILL BE VOLUNTARY, AND THAT ALL SUSJECTS PARTICIPATING IN MR. HOODY'S STUDY HILL BE FREE TO HITHDRAW THEIR PARTICIPATION AT ANY TIME. I HAVE BEEN INFORMED OF THE TRUE INTENT OF HR. MOODY'S PROJECT AND THAT INFORHED COHSENT HILL BE USED FOR STUDENT PARTICIPATION.

$11-10 \cdot 88$

DATE
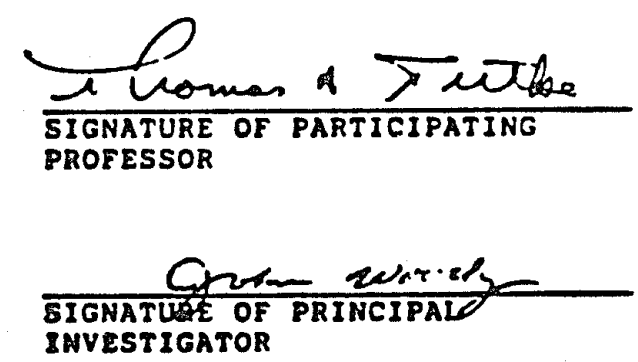

SUbIIttQd tO: HUMAN SUBJECT'S REVIEH DOARD SAN JOSE STATE UNIVERSITY

DATE N-10 - FH 